\title{
Engineering and hydrometeorological surveys on underexplored Arctic territories (through the example of the "Klyon" deposit, Russia)
}

\author{
Fedor Bryukhan ${ }^{1, *}$, Alexey Vinogradov ${ }^{2}$, and Alexey Kuchmin ${ }^{3}$ \\ ${ }^{1}$ Moscow State University of Civil Engineering, Yaroslavskoe sh. 26, 129337 Moscow, Russia \\ ${ }^{2}$ Saint Petersburg State Forest Technical University, Institutskiy per., 5, Saint-Petersburg, 194021, \\ Russia \\ ${ }^{3}$ NPO Gidrotekhproekt, Oktyabr'skaya str. 55A, 175400 Valday City, Novgorod Region, Russia
}

\begin{abstract}
The article describes the results of engineering and hydrometeorological survey on the gold-silver deposit "Klyon" (Bilibinskiy district, Chukotka Autonomous Region). The research primary goal is to obtain general data for designing of deposit production facilities and infrastructure. Climatic conditions of the deposit territory and its hydrological regime is briefly described giving corresponding quantitative characteristics. The article notes the need for temporary observation posts in remote territories to link such points to the existing hydrological and meteorological stations and to more accurately define hydrological and climatic regime characteristics.
\end{abstract}

\section{Introduction}

Engineering and hydrometeorological survey on the underexplored and hard-to-reach Arctic territories involves serious challenges. The main ones are sparse network of regular observation points, short field season, remoteness from settlements, lack of transport, etc. [1, 2]. Therefore, the use of library data and computational methods plays an important role in the engineering and hydrometeorological survey. It should be noted that at the construction stage of developing such remote territories, temporary observation points need to be arranged to link them to the existing hydrological and meteorological stations and to more accurately define hydrological and climatic regime characteristics.

The article presents the main results of engineering and hydrometeorological survey on the gold-silver deposit "Klyon" territory (Bilibinskiy district, Chukotka Autonomous Region). The survey was carried out by Scientific \& Industrial Association Gidrotekhproekt. This survey was aimed at obtaining initial hydrometeorological data for designing of "Klyon" deposit production facilities and infrastructure.

To accomplish the set objectives, a range of necessary field and office works were performed, including:

- data collection, analysis and processing;

\footnotetext{
*Corresponding author: pniiis-gip@mail.ru
} 
- preliminary site investigation;

- hydrological survey of the main water bodies (Klyon and Alisa streams);

- survey of water catchments and water bodies environs, determination of water catchment areas;

- leveling of water elevations;

- leveling of river cross-sections;

- measurement of water levels and flow rates;

- studying ice conditions of watercourses and river bed evolution;

- calculations of climatic and hydrological regime characteristics.

The survey was carried out in accordance with the requirements of engineering survey regulatory and technical documents [3].

View of the deposit territory from the helicopter is shown in Figure 1.

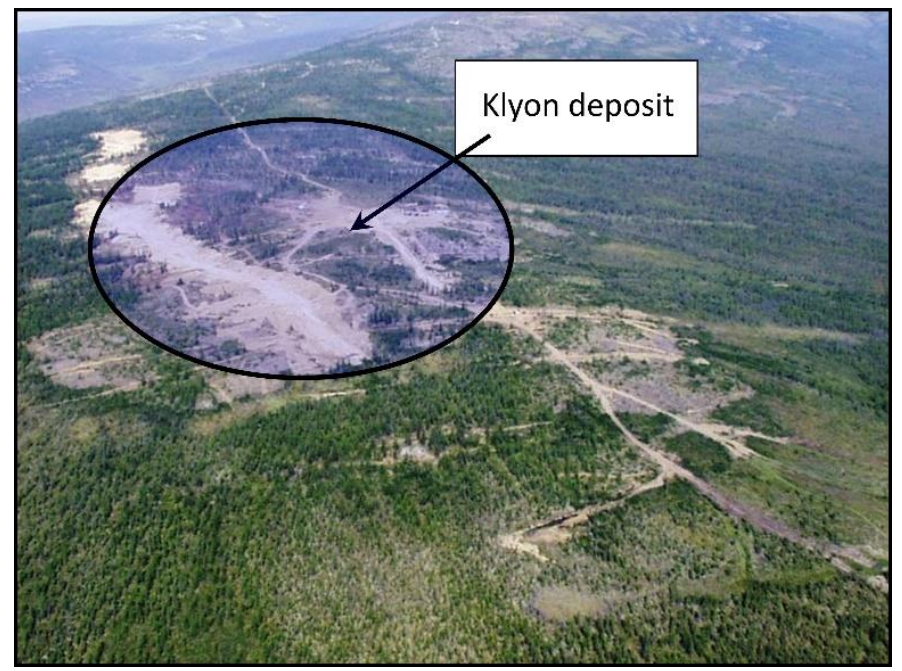

Fig. 1. View of the deposit territory from the east.

\section{Climatic regime}

A climatic regime of the territory was studied mainly based on the data from the nearest meteorological station Ust-Oloy with the use of library reference climate data. In addition to the climate data, the data of the Russian meteorological service standard long-term observations archive was used.

This area is characterized by severe winters with an average January temperature below $-38^{\circ} \mathrm{C}$. Winter lasts 7 months (from October to April). Cloudless weather is predominant during long winter. Winter sets in very quickly after an intermediate period of 1-2 decades.

\section{Air temperature.}

Average annual air temperature is $-12.2^{\circ} \mathrm{C}$. Average daily temperatures rise above zero in the second decade of May, and fall below zero in the second decade of September. Temperature drops quickly in early winter (in October). Severe frosts are observed already in November. The lowest temperatures are observed in January, the highest ones - in July. A characteristic feature of the thermal regime is large annual temperature amplitudes reaching $80-90^{\circ} \mathrm{C}$. Period with average daily subfreezing air temperature lasts 234 days. Average temperature of this period is $-23.5^{\circ} \mathrm{C}$. Frost-free period lasts 51 days on the average from June 7 to July 29. 


\section{Soil temperature and cryogenic conditions.}

Soil surface temperature is very close to the air temperature throughout the year. Permafrost rock is widespread throughout the studied area. The permafrost thickness varies from 100-300 $\mathrm{m}$ in the lowlands to 300-500 $\mathrm{m}$ in the mountain areas. Seasonal thaw depth of the soil depends on its compaction, loose component granulometric composition, degree of moistening, presence of vegetation, slope exposure and is $0.8-1.8 \mathrm{~m}$ in mountainous areas, $0.3-0.4 \mathrm{~m}$ in the plains. Throughout the year, soil surface temperature varies from $-36^{\circ} \mathrm{C}$ in winter to $15^{\circ} \mathrm{C}$ in summer.

\section{Air humidity.}

Water vapor partial pressure rises rapidly from winter to summer (from 0.3 to $10.0 \mathrm{hPa}$ at an average annual value of $3.6 \mathrm{hPa}$ ), while relative humidity throughout the year varies insignificantly (62-80\% at an average annual value of $73 \%)$.

\section{Atmospheric precipitations.}

Atmospheric precipitation regime throughout the year is determined by cyclonic activity and is associated with atmospheric fronts. Minimum monthly precipitation is observed from February to May and is 9-13 mm. Maximum precipitation is in July-August and reaches 40$49 \mathrm{~mm}$. Mean annual precipitation is on the average $266 \mathrm{~mm} .45 \%$ of precipitation is rain, 7 $\%$ is mixed (rain and sleet) and $48 \%$ is solid (snow) precipitation. In summer, precipitation most often falls in the form of heavy shower. Its maximum intensity for 1 hour is $0.1 \mathrm{~mm}$ per minute, and during the day $-0.02 \mathrm{~mm}$ per minute. Average duration of heavy shower $(\geq 2.0$ $\mathrm{mm})$ is 4.8 hours.

\section{Snow cover.}

Stable snow cover sets in early October, and at altitudes of over $600-700 \mathrm{~m}$ - in the last days of September. Average date of snow cover occurrence is September 20, average date of stable snow cover formation is October 5. Average number of snow cover days is 228 . Average date of stable snow cover destruction is May 17. Average date of snow cover loss is May 21. Snowfalls in the studied area are accompanied by strong winds. Often there are heavy snowdrifts on the roads. Estimated snow cover height with a probability of exceeding $5 \%$ is $85 \mathrm{~cm}$. The largest water reserve in the snow cover is $176 \mathrm{~mm}$. Snow pressure standard value is $1.5 \mathrm{kPa}$.

\section{Wind.}

Regional wind regime is characterized by predominance of the winds blowing along the river valleys. Northern and northwestern as well as southern and southeastern winds prevail throughout the year. At the same time, throughout the year there is a high repeatability of calms, associated with frequent anticyclonic weather. Throughout the year, wind speeds are insignificant $(1-2 \mathrm{~m} / \mathrm{s})$. Winds of over $15 \mathrm{~m} / \mathrm{s}$ are rarely observed and most often in the second half of summer and early autumn. According to the wind pressure climatic zoning map [4], the deposit territory is classified as the $2^{\text {nd }}$ wind region with a standard pressure of $0.30 \mathrm{kPa}$.

\section{Atmospheric phenomena.}

Average number of fogy days is 6.1, the largest number is 21 days. Average duration of fogs during the year is 27 hours. Most often, fogs are observed in winter and autumn periods. In winter months, frost fogs last sometimes 5-8 days. Fog layer thickness does not usually exceed 100-200 m. Horizontal range of visibility in frost fog is within 100-150 m, and in dense fogs it can decrease down to less than $10 \mathrm{~m}$.

Thunderstorms in the studied area are observed from June to August and are quite rare. However, they may be intensive. Particularly strong thunderstorms are associated with cold atmospheric fronts. Number of thunderstorm days per year is 3.8. Average duration of thunderstorms per year is 4.3 hours.

Snowstorms begin in September and last till May. Their duration and intensity are usually insignificant. Average number of snowstorm days per year is 12.7 , their average duration is 6-8 hours. 
Icing phenomena are usually observed as crystallized rime. Average number of days with ice accretion indicator wires icing is 22.4 per year, the largest number is 50 days. Mass of rime deposits is $40 \mathrm{~g} / \mathrm{m}$. According to ice wall thickness climatic zoning map [4], the "Klyon" deposit territory is near the border separating the $2^{\text {nd }}$ and $3^{\text {rd }}$ icing regions. Taking into account poor exploration degree of this territory, the most unfavorable icing conditions should be assumed for it: the $3^{\text {rd }}$ icing region and corresponding standard ice wall thickness of $10 \mathrm{~mm}$.

\section{Hydrological regime}

The deposit area main watercourses are the Klyon and Alisa streams. Both watercourses were studied as part of the survey, but the Alisa stream was studied in more details. This circumstance is because water will be drawn from this stream for household and drinking supply. The Alisa stream flows from north to south along the hollow between separate hills of the Oloy Ridge northern spurs. On the left, the stream flows into the Rakovskiy River, the right tributary of the Krichalskaya River, which is the left tributary of the Bolshoy Anyuy River. The Bolshoy Anyuy River originates from the Anadyrskoye plateau. By joining with the Maly Anyuy River it forms the Anyuy River - the right tributary of the Kolyma River. The latter flows into the Kolyma Gulf of the East Siberian Sea. Thus, the Klyon and Alisa streams are part of the Kolyma River basin.

The Alisa stream is classified as a small watercourse. Its length from the source to the designed water intake cross-section is $2.2 \mathrm{~km}$, from the source to the designed wastewater outlet is $6.8 \mathrm{~km}$. The catchment areas are 4.3 and $16.0 \mathrm{~km}^{2}$, respectively. The stream valley is straight, stretched from the northwest to the southeast. The Alisa stream floodplain is narrow, in some places one-sided, of up to $20-50 \mathrm{~m}$ wide. The Alisa stream is $1.5-2.0 \mathrm{~m}$ wide, the bed in the edges is $0.4-0.6 \mathrm{~m}$ deep, low water is $0.2-0.3 \mathrm{~m}$ deep. Flow velocity in low water varies within $0.1-0.2 \mathrm{~m} / \mathrm{s}$ in the reaches within $0.5-0.7 \mathrm{~m} / \mathrm{s}$ on shallows. Scheduled bank deformations are weak and do not exceed $1.5 \mathrm{~m}$ in each direction during technogenic impact in earlier geological survey. The longitudinal slope measured in field works is 36-42 $\%$, bed roughness coefficient is 0.050 , that of the floodplain is 0.080 . The Alisa stream bed is slightly sinuous, strongly incised. All deformations in the bed are caused by moving ridges and mesoforms according to the scheme of lateral or band-ridge type of bed processes. Maximum planned erosion of the Alisa stream during the planned deposit operation period of 30 years will not exceed $1.5 \mathrm{~m}$. Erosion is possible towards both banks. Minimum elevation of stream bed limit erosion profile in the designed range is $379.24 \mathrm{~m}$ of the Baltic elevation system. Maximum elevation for thalweg alluvium is $380.52 \mathrm{~m}$ of the Baltic system.

Hydrological regime of the Alisa stream has not been studied before. Fieldworks were carried out as part of engineering survey from August 8 to August 28, 2012. The survey involved obtaining necessary data for subsequent calculations of hydrological regime characteristics. Estimated flow characteristics were determined using standard methods. To assess water regime in the designed cross-sections, the Russian meteorological service observation materials for the similar rivers of surveyed area with relatively long series of observations were also used:

- Topolevka River (cross-section is Dalny village);

- Peymyna River (cross-section is $1.5 \mathrm{~km}$ from the mouth);

- Baimka River (cross-section is Baimka village).

The main features of the Bolshoy Anyuy basin watercourses regime are determined by severe climatic conditions, rugged relief, widespread permafrost. The water regime is characterized by a very uneven intra-annual flow distribution peculiar to the rivers of Eastern Siberia and northern Far East:

- high spring flood; 
- frequent summer high waters, which usually do not reach spring floods in terms of volume, but can exceed maximum water flow rates for small rivers;

- winter low water.

The watercourses have mixed inflow sources: snow (47\%), rain (42\%) and underground (11\%) sources. Spring-summer flow is $90-95 \%$ of the annual volume. Its greatest part falls to spring flood: $40-50 \%$ of the annual volume.

\section{Flood.}

The Bolshoy Anyuy River basin is characterized by pronounced snow flood. Winter precipitation amounts to $75-100 \mathrm{~mm}$. Snow melting intensity is determined by air temperature variation and the cold returns specific to the territory under consideration during spring flood. Flood usually begins in the third decade of May, its peak takes place in the first decade of June and ends in the second half of June. Due to return of cold weather spring flood is divided into a series of peaks. During snowmelt period, level fluctuations are effected by intra-diurnal variation with amplitude of 0.1-0.2 m due to daily variation of solar radiation. Flood peak may be superimposed by some rainfall high waters. Flow middle layer for the period of high water in the Bolshoy Anyuy River basin is $80-120 \mathrm{~mm}$, rainwater share is 10 $15 \%$ of the total flood flow.

\section{Summer low water and rainfall high water.}

In summer, after spring flood, water regime is entirely determined by the nature of precipitation. In summer, the water level drops and only during rainy season there is a rise in water and short-term high waters are observed. High water period begins in June and lasts until September. Rainfall high waters on the Alisa stream can be observed in any month of the warm period. During warm period, the number of rainfall high waters can be 3 to 5 and sometimes more. During this period, hydrograph becomes comb-shaped. High water duration usually does not exceed 10 days.

The main factors determining the magnitude of maximum water flow and the volume of high water flows are intensity and layer of rainfall as well as the moisture preceding rain. The periods between high waters are short. The greatest high waters are more frequently observed in July-August.

Summer low-water period, as a rule, begins in the second half of summer and ends with autumn high water. Low water time of occurrence and its duration are determined by noprecipitation period. Average duration of low water period is 20 days. In some especially dry years, low water can last throughout the entire summer. In autumn, rivers inflow by rain falls as the amount of precipitation decreases. Autumn flow share is 5-6\% of the annual volume. In September, the levels begin to fall as temperature decreases and rains end. Shore fast ice appears in the mid-September and in the first decade of October.

\section{Winter low water.}

Winter low water period accounts for $0.5-2 \%$ of the annual flow volume. The Alisa stream freezes through every winter.

\section{Level and flow regimes.}

The highest water level in water intake cross-section is $381.44 \mathrm{~m}$ of the Baltic system, in the outlet cross-section $-237.98 \mathrm{~m}$. Maximum water flow on the floodplain is $0.2-0.5 \mathrm{~m}$. At the same time the floodplain is flooded for a width of at most $10-15 \mathrm{~m}$. The Alisa stream flow rate in the design water intake cross-section is $30.1 \mathrm{dm}^{3} / \mathrm{s}$, in the outlet cross-section -112 $\mathrm{dm}^{3} / \mathrm{s}$. Maximum water flow rate in floods is less than that of high waters. The maximum high water flow rate $Q_{\max }$ in the water intake cross-section is $6.62 \mathrm{~m}^{3} / \mathrm{s}$, and $18.8 \mathrm{~m}^{3} / \mathrm{s}$ in the outlet cross-section. The minimum summer water flow rate $Q_{\min }$ in the design water intake cross-section is $0.009 \mathrm{~m}^{3} / \mathrm{s}$.

Ice regime. In winter, the Alisa stream freezes through for 3-6 months. Freezing-over duration is on the average 230-260 days. From the west of the survey site, there is the Klyon stream. This article does not describe it in detail, since it does not have a hydrological effect 
on the "Klyon" deposit territory. The study has revealed that the Klyon stream is more waterabundant, wider and deeper than the Alisa stream. Hydrologically, it is more suitable for use as a water source and a wastewater receiver than the Alisa stream. However, it is located further from the designed facilities of the deposit and is less convenient for use.

\section{Hydrological and meteorological monitoring}

As we already noted above, the "Klyon" deposit territory is practically not studied in both climatic and hydrological terms. At the same time, deposit operation requires both current observation data as well as climatic and hydrological regimes updated data. Due to this circumstance, a meteorological observation post was arranged for the period of facility construction and operation. Similarly, by the beginning of construction, hydrometric observation posts had been arranged on the Klyon and Alisa streams to obtain regular information on current hydrological conditions. Hydrometeorological observation program at temporary observation points is linked to environmental monitoring program.

\section{Conclusions}

- The article describes the results of "Klyon" deposit territory climatic and hydrological regimes study obtained as part of engineering survey.

- Data on the studied territory climatic conditions and characteristics of its hydrological regime are obtained.

- The article notes the need for temporary observation posts in remote territories to link such points to the existing hydrological and meteorological stations and to more accurately define hydrological and climatic regime characteristics.

\section{References}

1. Y. Gao, J. Sun, F. Li et al., Advances in Atmospheric Sciences, 32, 92-114 (2014)

2. S.A. Krogh, J.W. Pomeroy, P. Marsh, Journal of Hydrology, 550, 685-703 (2017)

3. Russian State Standard SP 47.13330.2012. Engineering surveys for construction, basic principles: Updated edition of SNiP11-02-96 (Ministry of Regional Development of Russia, Moscow, 2012)

4. Russian State Standard SNiP 2.01.07-85*. Loads and effects (Gosstroy of the USSR, 2012) 